\title{
Coercion in Substance Use: A Systematic Review
}

\author{
Steffi Rose Mathew*1, Anil BA² and Jobin John ${ }^{3}$ \\ ${ }^{1}$ Trainee Pharmacist, Care and Cure Pharmacy, Qatar \\ ${ }^{2}$ Principal, Westfort College of Pharmacy, India \\ ${ }^{3}$ Registered Pharmacist, India
}

\begin{abstract}
Background: Substance use coercion is a severe form of abuse that leads to Intimate Partner Violence (IPV) and sexual exploitation. It also leads to mental health problems and continuous victimization of individuals by abusive partners. Substance use coercion is a significant issue with less attention provided and can be traced as a vital factor in crimes such as sex trafficking.

Method: The following is a systematic review conducted as per Preferred Reporting Items for Systematic Reviews and MetaAnalyses (PRISMA guidelines). The databases Google Scholar and PubMed were searched on September 2020, from January 1, 2000, to August 31,2020. The studies considered were either telephone surveys or face-to-face interviews, and the study subjects included the general population. The details were extracted from the published articles.
\end{abstract}

Findings: 4 studies and a legal case file on substance use coercion were identified and had 3207 subjects involved. The reciprocal relation between substance use coercion and IPV or sexual assault was discussed, and the results were descriptively summarized on the cumulative evidence from studies included.

Interpretation: The possibility of reduction of sexual assaults and IPV by reducing substance use coercion were identified. Counseling in schools may identify and prevent childhood abuse that pertains to sexual assaults and substance use in the future. Also, awareness related to substance use and sexual exploitation may prevent such scenarios in adolescent life.

KEYWORDS: Coercion; Substance abuse; Intimate partner violence; Human trafficking; Domestic violence

\section{INTRODUCTION}

Substance use coercion or forced substance use is a form of violence correlating to abusive tactics related to control and manipulating the victims. This can breed IPV or domestic violence [1]. It can facilitate sexual assaults and is used mostly by someone close to the victim. This can lead to mental distress, such as depressive disorders or post-traumatic stress disorders. Addiction is another condition that can stem from substance use coercion [2]. Therefore, identification and tackling of substance use coercion are of significance.

The following review assesses the occurrence of substance use in households and among adolescents, its relation to IPV, sexual assault, sex trade, and concludes on possible methods to tackle the situation.

\section{METHODS}

\section{Search Strategy and Selection Criteria}

The following is a systematic review conducted as per PRISMA guidelines (Figure 1). The inclusion criteria for the study were to assess the coercion of substance use in the general population. The studies were observational and conducted as face-to-face interviews, web surveys, or legal case files from U.S. Attorney Bulletin. Studies not pertaining to the coercion aspects of substance use were excluded.

The databases Google Scholar and PubMed were searched on September 2020, from January 1, 2000, to August 31, 2020. The terms searched for both databases included "substance use

\begin{tabular}{|c|l|}
\hline Quick Response Code: & $\begin{array}{l}\text { Address for correspondence: Steffi Rose Mathew, Trainee Pharmacist, Care and } \\
\text { Cure Pharmacy, Qatar }\end{array}$ \\
\cline { 2 - 2 } & $\begin{array}{l}\text { Received: April 19, } 2021 \quad \text { Published: June 28, } 2021 \\
\text { How to cite this article: Steffi RM, Anil BA, Jobin John. Coercion in Substance Use: A Systematic } \\
\text { Review. 2021- 3(3) OAJBS.ID.000297. DOI: 10.38125/OAJBS.000297 }\end{array}$ \\
\hline
\end{tabular}


coercion", "substance dependence”, "dipsomania”, substance abuse”, "drug addiction" and "coercion". No unpublished studies were considered, and a descriptive summary of data was included. The following study had no protocol.

\section{Data Analysis}

The data were extracted manually by assessing the abstracts through the databases. Identified articles were downloaded and collected into Microsoft word document. Duplicated data were identified and removed manually between the processes of data analysis.

The total sample included, age, gender, the growth scale, ethnicity, type and assessment of study, substance involved, and source of coercion were the variables considered.

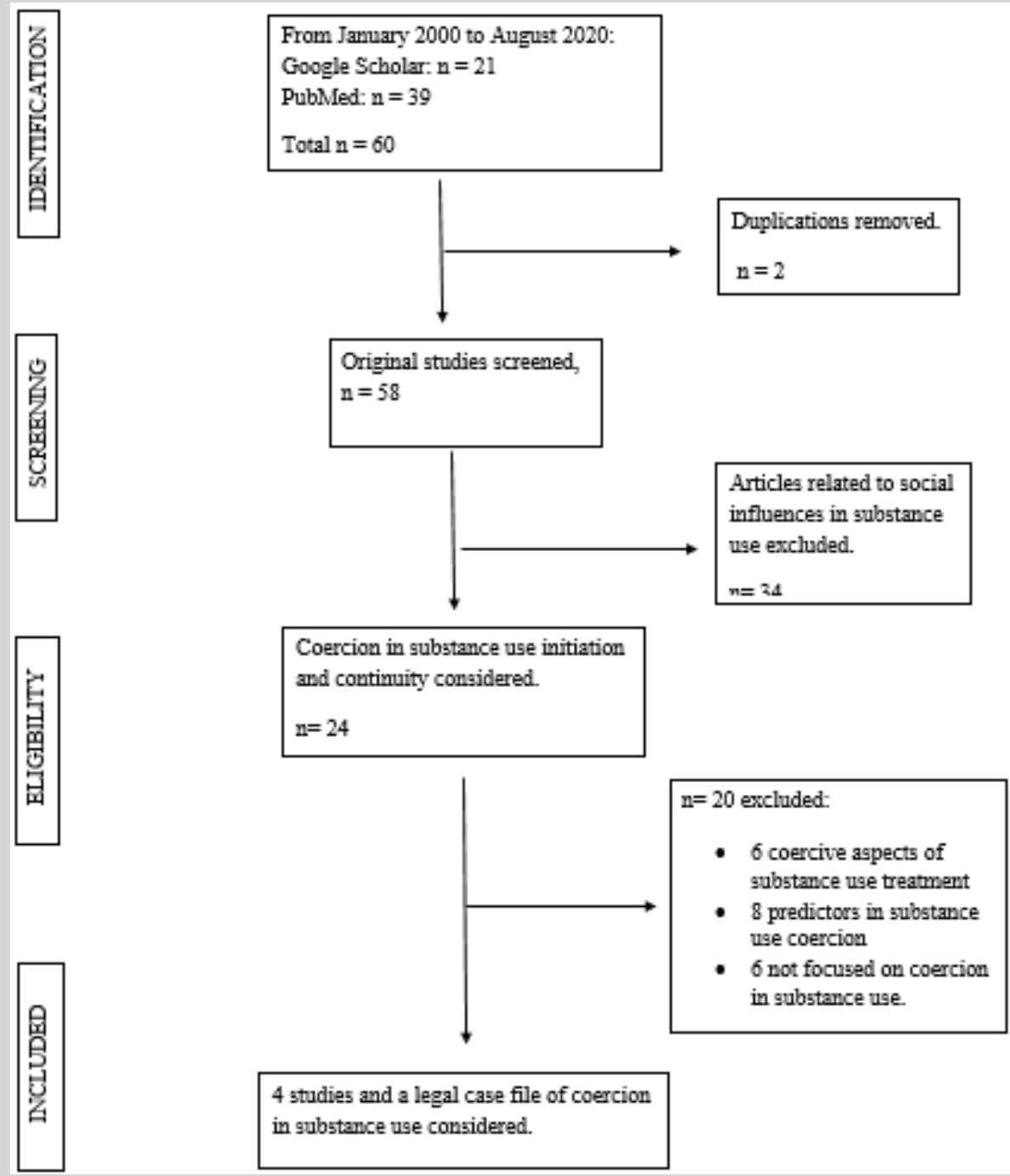

Figure 1: PRISMA flow diagram for the selection of articles included in the analysis.

\section{RESULTS}

Studies on coercion in substance use were less in the past two decades. 4 studies and a legal case file eligible on coercive substance use were identified with 3207 patients. The adolescent groups were the primary target of the majority of studies. Details of studies on coercion in substance use are given in Table 1, respectively.

Substance use coercion in sexual coercion was experienced by $8 \%$ out of 24 in high school, $9 \%$ out of 83 in college [3], and five out of 19 gay/bisexual men [4] Prior to sexual coercion, the perpetrators encouraged the use of [3] or manipulative incapacitation by alcohol/drugs or exploitation of intoxicated state [4]. Two of five men were victims of deliberate and manipulative drug rape in which the perpetrator used drugs without their knowledge while under the influence of alcohol. Another experienced coerced sex due to deliberate incapacitation by alcohol, and two others were exploited in their intoxicated state in a circumstance where one respondent used alcohol to boost his confidence to approach another man.

A substance use coercion survey conducted identified that $95.4 \%$ of victims were female, and 36- to 45-year-olds experienced the highest rates of substance use coercion [5]. A set of questions assessed the tactics involved in coercion (Table 2), and the majority of survivors experienced more than one tactic (Table 3).

Respondents who tried to seek help for substance abuse reported that $60.1 \%$ experienced discouragement from their partner or expartner, out of which $94 \%$ were threatened with exposure and 92.4\% experienced threat about exposing their substance use to authority [5]. In the substance coerced sex trade, a legal case had two victims, where the perpetrator portrayed himself as 'protector' 
of the minor victim, encouraged and force-fed prescription pain pills [6]. Similarly, 11 out of 16 victims were introduced to potent drugs like cocaine or heroin [7]. Both developed an addiction, and traffickers exploited this addiction for coercing them into prostitution in exchange for drugs [6,7]. In two other legal cases, 7 victims previously addicted to heroin were coerced to commit commercial sex by manipulating or withholding their drug supply, which created a fear of 'withdrawal sicknesses' and contributed to the act of coerced prostitution [6]. Also, the substance use tactic in sex trade recruitment was primarily employed by non-romantic partners [7].

Table 1: Details of studies assessed in the review.

\begin{tabular}{|c|c|c|c|c|c|}
\hline $\begin{array}{c}\text { Author \& Year of } \\
\text { publication }\end{array}$ & $\begin{array}{c}\text { Participants } \\
\text { (Sample Size and } \\
\text { Age) }\end{array}$ & $\begin{array}{c}\text { Other } \\
\text { Demographic } \\
\text { details (Ethnicity, } \\
\text { Growth stage, } \\
\text { Gender and } \\
\text { country) }\end{array}$ & $\begin{array}{c}\text { Type of Study and } \\
\text { Assessment }\end{array}$ & Substance Used & Coerced By \\
\hline \multirow[t]{2}{*}{ Bryan et al. [4] } & \multirow[t]{2}{*}{$107,15-19$ years } & \multirow{2}{*}{$\begin{array}{l}\text { Black, Adolescent } \\
\text { women, United States }\end{array}$} & $\begin{array}{l}\text { Cross-sectional study with } \\
\text { retrospective data from } \\
\text { Cecil and Matson's (2005) } \\
\text { seminal work. }\end{array}$ & \multirow[t]{2}{*}{ Alcohol and Drugs } & \multirow{2}{*}{$\begin{array}{l}\text { Romantic } \\
\text { partners }\end{array}$} \\
\hline & & & $\begin{array}{l}\text { Sexual Coercion Inventory } \\
\text { Questionnaire with short } \\
\text { description on incident } \\
\text { were assessed. }\end{array}$ & & \\
\hline \multirow[t]{2}{*}{ Bryan et al. [4] } & \multirow{2}{*}{$19,20-54$ years } & \multirow{2}{*}{$\begin{array}{l}\text { 57.8\% New Zealander, } \\
\text { 15.7\% Māori, 21\% } \\
\text { Asians and 5.2\% } \\
\text { Anglo-European. } \\
\text { Young adulthood to } \\
\text { adulthood }\end{array}$} & $\begin{array}{l}\text { Cross-sectional study } \\
\text { recruited via word of } \\
\text { mouth, snowballing, } \\
\text { community outreach and } \\
\text { advertisements in gay } \\
\text { settings. }\end{array}$ & \multirow{2}{*}{ Alcohol and Drugs } & \multirow{2}{*}{$\begin{array}{c}\text { Strangers or } \\
\text { casual partners }\end{array}$} \\
\hline & & & $\begin{array}{l}90 \text { to } 120 \text { minutes } \\
\text { interview of participants } \\
\text { relating to sexual coercive } \\
\text { experiences were } \\
\text { assessed. }\end{array}$ & & \\
\hline Warshaw et al. [5] & 3,056 & $\begin{array}{c}\text { Gay/Bisexual men, } \\
\text { Aotearoa/New } \\
\text { Zealand. 22\% African } \\
\text { American, 2.2\% } \\
\text { Asian American, 48\% } \\
\text { Caucasian, 20.5\% } \\
\text { Hispanic/Latina, 1\% } \\
\text { native American/ } \\
\text { Alaska, 0.2\% native } \\
\text { Hawaiian/Pacific } \\
\text { Islander, 0.5\% } \\
\text { Middle Eastern/ } \\
\text { Arab, Adolescence to } \\
\text { Adulthood women, } \\
\text { United States }\end{array}$ & $\begin{array}{l}\text { Voluntary surveys via } \\
\text { National Domestic } \\
\text { Violence Hotline callers } \\
\text { conducted in a period of } 6 \\
\text { weeks (February } 1,2012 \\
\text { to March } 14,2012 \text { ) with a } \\
\text { maximum of } 5 \text { questions. }\end{array}$ & Alcohol and Drugs & $\begin{array}{l}\text { Partner or Ex- } \\
\text { partner }\end{array}$ \\
\hline Roberson et al. [6] & $\begin{array}{l}9 \text { victims, } 3 \text { legal cases } \\
\text { of sex trafficking }\end{array}$ & $\begin{array}{l}\text { Adolescent to } \\
\text { adulthood Women, } \\
\text { United States }\end{array}$ & $\begin{array}{l}\text { Case files of Andrew } \\
\text { Fields 2013, Jeremy Mack } \\
\text { 2014, Monta Groce } 2016 \\
\text { included. }\end{array}$ & $\begin{array}{l}\text { Oxycodone, opioids, } \\
\text { heroin }\end{array}$ & $\begin{array}{l}\text { Romantic } \\
\text { Partners/ } \\
\text { strangers }\end{array}$ \\
\hline \multirow[b]{2}{*}{ Jiménez et al. [7] } & \multirow[b]{2}{*}{$16, \geq 18$ years } & \multirow{2}{*}{$\begin{array}{l}\text { Adolescence to } \\
\text { adulthood women } \\
\text { Tijuana and Ciudad } \\
\text { Juárez, Mexico-United } \\
\text { States border cities }\end{array}$} & $\begin{array}{c}\text { Qualitative study with } \\
\text { data collected from August } \\
2013 \text { to October } 2014 \\
\text { as part of study Mapa de } \\
\text { Salud. }\end{array}$ & & \multirow{2}{*}{$\begin{array}{c}\text { Mostly Strangers, } \\
\text { Family members, } \\
\text { Friend/ } \\
\text { Acquaintance }\end{array}$} \\
\hline & & & $\begin{array}{c}\text { Identified women } \\
\text { with coerced sex } \\
\text { trade experience via } \\
\text { quantitative survey } \\
\text { and in-depth interview } \\
\text { conducted and organized } \\
\text { for assessment }\end{array}$ & Cocaine or Crack & \\
\hline
\end{tabular}


Table 2: Details of studies assessed in the review.

\begin{tabular}{|c|c|}
\hline Substance Use Coercion Survey Assessment Questions & Percentage of Population Answered "Yes" \\
\hline $\begin{array}{c}\text { Has your partner ever pressured or forced you to use alcohol or other } \\
\text { drugs or made you use more than you wanted? }\end{array}$ & $27 \%$ \\
\hline $\begin{array}{l}\text { Has your partner ever threatened to report your alcohol or other drug use } \\
\text { to anyone in authority to keep you from getting something you want or } \\
\text { need (custody of children, job benefits, and protective order)? }\end{array}$ & $37.50 \%$ \\
\hline $\begin{array}{c}\text { Have you ever been afraid to call the police for help because your partner } \\
\text { or ex-partner said they wouldn't believe you because you were using or } \\
\text { you would be arrested for being under the influence of alcohol or other } \\
\text { drugs? }\end{array}$ & $24.40 \%$ \\
\hline $\begin{array}{l}\text { Have you ever used alcohol or other drugs as a way to reduce the pain of } \\
\text { your partner or ex-partner's abuse? }\end{array}$ & $26 \%$ \\
\hline $\begin{array}{l}\text { In the last few years, have you ever tried to get help for your use of alcohol } \\
\text { or other drugs? }\end{array}$ & $15.20 \%$ \\
\hline $\begin{array}{l}\text { Has your partner or ex-partner ever tried to prevent or discourage you } \\
\text { from getting help for your substance use? }\end{array}$ & $60.10 \%$ \\
\hline
\end{tabular}

Table 3: The cumulative tactic involved in the substance use coercion.

\begin{tabular}{|c|c|c|}
\hline Coercion Tactics Employed: & $\begin{array}{c}\text { Has your partner ever pressured or } \\
\text { forced you to use alcohol or other } \\
\text { drugs or made you use more than you } \\
\text { wanted }\end{array}$ & $\begin{array}{c}\text { Have you ever been afraid to call the } \\
\text { police for help because your partner or } \\
\text { ex-partner said they wouldn't believe } \\
\text { you because you were using, or you } \\
\text { would be arrested for being under the } \\
\text { influence of alcohol or other drugs }\end{array}$ \\
\hline $\begin{array}{c}\text { Has your partner ever threatened to report your } \\
\text { alcohol or other drug use to anyone in authority } \\
\text { to keep you from getting something you want } \\
\text { or need (custody of children, job benefits, } \\
\text { protective order) }\end{array}$ & $66.50 \%$ & \\
\hline $\begin{array}{c}\text { Have you ever been afraid to call the police for } \\
\text { help because your partner or ex-partner said } \\
\text { they wouldn't believe you because you were } \\
\text { using or you would be arrested for being under } \\
\text { the influence of alcohol or other drugs }\end{array}$ & & \\
\hline
\end{tabular}

\section{DISCUSSION}

Substance use coercion is a form of abuse and one of the possible tactics involved in sexual coercion, $[3,4]$ recruitment, and ensuring that women remain in the sex trade [6,7]. It is not just limited to adolescent girls [3,6,7] and women [5-7] but also includes gay/ bisexual men in their adolescence to young adulthood. (4) The perpetrators were male [2-7] and usually acquaintances/friends or strangers in bars or intimate/casual partners [3-7] Sexual assault that occurred under such circumstances can be attributed to the youth and inexperience of the victims. The perpetrator's experiences such as childhood sexual abuse, witnessed domestic violence, acceptance of male violence [8], and history of substance use [9] might have been the unexplored factor owing to these sexual assaults.

A sexual assault study of college male perpetrators revealed a higher number of female victims than male [9]. Contrary to typical beliefs, sexual assaults experienced by males and females are roughly equivalent, and gay/bisexual men experience more sexual assault than heterosexual men [10]. The assault cases of men not being pursued further may probably be due to the misconception of masculinity equals strength, the stigma of "men don't experience sexual coercion," and the belief that they will not be taken seriously.

The deliberate/manipulative substance use coercion, incapacitated, weakened the judgment and immobilized the victim prior to sexual coercion [3,4]. $75 \%$ of all acquaintance rape are facilitated by either alcohol/drugs or both and are referred to as date-rape drugs. Drug facilitated sexual assault occurs when the victim involuntarily or voluntarily or both, ingests an intoxicating substance [11]. The gay/bisexual men consumed alcohol prior to the incident and were incapacitated during the assault $[4,10]$. Approximately half of college student's sexual assaults were associated with alcohol use [12]. Also, in some cases, both perpetrator and victim were alcohol intoxicated [8,12]. Alcohol is the most common drug in sexual assault for its CNS depressant properties [11]. Intoxication leads to restricted motor skills, less thought, and coordinated responses, and increased aggression for men. In females, it lowers the ability to defend themselves, makes them less aware of men's threatening behavior, and hard to resist or engage [12]. Though substance use coercion was not the primary tactic applied by perpetrators, it was identified to play a critical role [3,4]. The deliberate use of drugs /alcohol or both by the perpetrators, with or without the victims' awareness, gave the advantage of less resistance, loss of consciousness, and created confusion in the minds of victims regarding consent in sexual intercourse. Also, the intoxication of the perpetrator may impair his judgment that paves into sexual assault scenarios.

Substance use coercion in sex trafficking mainly exploits a victim's addictive behavior [4,5]. More than $70 \%$ of trafficked victims reported using substances. Social determinants that breed insecurities (such as food, job insecurity, unstable housing, 
limited access to healthcare, and other support systems) promote increased manipulation of especially minors into the sex trade. The traffickers encourage or force substance use as it will guarantee the dependence, incapacitation, and control of victims, make them incur debt and vulnerable to the trafficker. Traffickers manipulate a victim's drug supply and use drugs to lure in persons with an established drug problem and use it as a reward for their compliance. Withdrawal symptoms occur due to the cessation of the addicted drug.

This leads to individuals suffering from extreme physical and emotional withdrawal. This instills fear in users and is used by the traffickers to obtain prostitution. Increased vulnerability and drug dependence are integral tools used by the trafficker [13]. It also diminishes the victim's judgment, ability to resist, and have no control of their situation. Besides, many traffickers know that the drug use by those trafficked helps them avoid criminal charges as when apprehended by law enforcement, victims' drug use may make them lose their credibility and presumed innocence, distracting from their victimization [14].

Substance use coercion was also found within households and resulted in domestic sexual coercion and intimate partner violence (IPV). IPV can lead to substance dependence as it helps to cope. $69.7 \%$ reported that substance use helped reduce pain and cope with domestic violence. A high prevalence of co-existence of IPV and substance use was identified, and their relationship was bidirectional. Substance use by an abusive partner may lead to IPV, or IPV leading to mental health conditions might induce the start of substance use [15].

Forcing to use the substance, threatening to report to authorities, misleading them into believing the authorities will not help them, or they would be arrested for using substance were the coercion tactics applied. The abusive partners made the victims feel insane and sexually assaulted them in their intoxicated state. Sabotaged or discouraged them from getting addiction treatment as addiction made the partners easier to control and would rely on abusive partners for substance supply [16].

\section{CONCLUSION}

Creating awareness among adolescents regarding substance use coercive tactics, substance ingestion effects, and its possibility of sexual exploitations may help tackle sexual coercion related to substance use. Experience of childhood abuse and witnessing domestic violence are rising concerns that pertain to both being a victim and perpetrator in sexual assault as these factors mold the individuals into adjusting to the idea of abuse and would most probably see it as something familiar in their lives.

Counseling and awareness programs conducted in schools may help identify these victims and help them out of the trauma. Also, identifying homeless minors and substance using females with an inadequate background in the general population might reduce the number of victims available for sex traffickers to manipulate the sex trade. Detection of substance use coercion in households and extending help to victims may reduce IPV, help them receive treatment, and protect them from abusive partners.

The number of studies on coercion in substance use was significantly less in the last 20 years as many people might not even realize that they were subjected to substance use coercion or may not be willing to admit that they use the substance, which implies a lack of attention given to the topic, irrespective of its significance.
The majority of abuse and crimes related can be rectified by preventing substance use coercion and increasing awareness among the public.

\section{FUNDING SOURCES}

This research did not receive any specific grant from funding agencies in the public, commercial, or not-for-profit sectors.

\section{REFERENCES}

1. Soper RG (2014) Intimate partner violence and co-occurring substance abuse/addiction. American Society of Addiction Medicine.

2. Guarnotta E (2019) Effects of drug and alcohol related sexual assault. American Addiction Centers.

3. French BH, Neville HA (2008) Black teenage girls' experiences with sexual coercion: Context, coping, and consequences. black women, gender families 2(2): 77-98.

4. Braun V, Schmidt J, Gavey N, Fenaughty J (2009) Sexual coercion among gay and bisexual men in aotearoa/new zealand. Journal of Homosexuality 56(3): 336-360.

5. Warshaw C, Tinnon E (2014) Mental health and substance use coercion surveys report. National Center on Domestic Violence, Trauma \& Mental Health.

6. Roberson L, Patel S (2017) Prosecuting sex trafficking cases using a drug-based theory of coercion. Journal of Federal Law and Practice 65(6): 175-184

7. Rocha Jiménez T, Salazar M, Boyce SC, Brouwer KC, Staines Orozco H, et al. (2018) We were isolated, and we had to do whatever they said: Violence and coercion to keep adolescent's girls from leaving the sex trade in two US-Mexico border cities. Journal of Human Trafficking, 5(4): 312-324.

8. Lyndon AE, White JW, Kadlec KM (2007) Manipulation and force as sexual coercion tactics: conceptual and empirical differences. Aggressive Behavior 33(4): 291-303.

9. Williams KS, Bierie DM (2014) An incident-based comparison of female and male sexual offenders. sexual Abuse: Journal of Research and Treatment 27(3): 235-257.

10. Hequembourg AL, Parks KA, Collins RL, Hughes TL (2014) Sexual assault risks among gay and bisexual men. The Journal of Sex Research 52(3): 282-295.

11. Busardò FP, Varì MR, Trana Adi, Malaca S, Carlier J, di Luca NM, (2019) Drug-facilitated sexual assaults (DFSA): a serious underestimated issue. Eur Rev Med Pharmacol Sci 23(24): 10577-10587.

12. Abbey A, Clinton AM, McAuslan P, Zawacki T, Buck PO (2002) Alcoholinvolved rapes: Are they more violent? Psychol Women Q 26(2): 99-109.

13. Meshelemiah JCA, Lynch RE (2019) The weaponization of drugs. In the cause and consequence of human trafficking: Human rights violations, Ohio State University Pressbook. USA. pp. 127-142.

14. Meshelemiah JCA, Gilson C, Prasanga APA (2018) Use of drug dependency to entrap and control victims of sex trafficking: A call to a U.S. federal human rights response. Dignity: A Journal on Sexual Exploitation and Violence 3(3).

15. Rivera EA, Phillips H, Warshaw C, Lyon E, Bland PJ, et al. (2015) An applied research paper on the relationship between intimate partner violence and substance use. National Center on Domestic Violence, Trauma \& Mental Health, Chicago, USA

16. Lowry F (2019) Forced drug abuse a hidden but disturbingly common part of domestic violence. Medscape. 